\title{
Alternative treatment approaches of urinary tract infections caused by uropathogenic Escherichia coli strains
}

\author{
Beata Zalewska-Piątek ${ }^{凶}$ and Rafał Piątek \\ Departments of Molecular Biotechnology and Microbiology, Gdańsk University of Technology, Gdańsk, Poland
}

\begin{abstract}
Urinary tract infections (UTIs) are the most widespread and annoying infections affecting millions of people every year annually. The biggest problems of urinary diseases are recurrences, increasing resistance of uropathogens to commonly used antibiotics, as well as the high health care costs of afflicted persons. Uropathogenic Escherichia coli strains (UPECs) are the most dominant etiologic agents of community-acquired infections of this type. During UTI pathogenesis, UPECs utilize various virulence factors, especially mono- and polyadhesive appendages of the chaperone-usher secretion pathway (CUP) required for adhesion, invasion and biofilm formation. Commonly used antibiotics for UTI treatment are usually effective, but their long-term utility may affect gut microbiota of the treated individuals and cause selection of drug resistant uropathogenic variants. Due to increasing resistance of UPEC strains to antibiotics via the evolution of specific defense mechanisms, there is a need to develop alternative methods and therapeutic strategies to fight UTIs (vaccines, receptor analogues, pilicides and curlicides, bacterial interference or phagotherapy). Such therapeutic approaches usually target processes enabling uropathogens to survive within the urinary tract and cause recurrent infections.
\end{abstract}

Key words: uropathogenic E. coli, urinary tract infections, chaperoneusher pathway, adhesins, vaccines, pilicides

Received: 07 March, 2019; revised: 26 April, 2019; accepted: 29 April, 2019; available on-line: 28 May, 2019

๑e-mail: beazalew@pg.edu.pl

Acknowledgements of Financial Support: This work was supported by the Polish National Science Centre Grant 2014/13/B/ NZ6/00257 (to R. P.).

Abbreviations: $A B U$, asymptomatic bacteriuria; CAUTIs catheter-associated infections; CUP, chaperone-usher secretion pathway; DAF decay-accelerating factor; DSE, donor strand exchange; DSC, donor strand complementation; ECs, uropathogenic E. coli; FyuA, yersiniabactin ferric uptake receptor; Gal, galactose; GalNAc, N-acetylgalactosamine; Hma, haem acquisition protein; HlyA, haemolysin; HSV-1, Herpes simplex virus type 1; IreA, iron-responsive element, IroN iron uptake receptor; lutA, aerobactin iron transport receptor; TLR4, toll-like receptor 4; TF, Thomsen-Friedenreich; UPIBCs, intracellular bacterial communities (IBCs); UTIs, urinary tract infections; QIRs, quiescent intracellular reservoirs

\section{INTRODUCTION}

Urinary tract infections (UTIs) are one of the most dominant bacterial infections among humans, accounting for up to 150 million registered cases per year worldwide. UTIs cause a wide-ranging health problem and economic burdens for the countries resulting from the need to treat or hospitalize individuals affected by the infections of this type (Stam \& Norby, 2001; Cassini et al., 2016). In the United States, these infections consti- tute the reason for 100000 hospital admissions and 11 million medical visits annually. They also represent at least $40 \%$ of infections directly acquired in the hospitals (Foxman, 2014).

UTIs affect women more often than men. It is estimated that $50 \%$ of women suffer from UTI at least once in their lifetime and above 30\% undergo antibiotic therapy due to UTI before the age of 24 (Foxman, 2002; Foxman, 2014). A total of $20-40 \%$ of the afflicted women also experience one or more recurrent infection within months of the first episode of UTI. In turn, frequent recurrences of infection require repeated antibiotic therapy. Such UTI treatment promotes the development of drug resistance among uropathogens (Franco, et al., 2005; Terlizzi et al., 2017).

UTIs are caused by a range of various pathogens but the most frequent causative agents for complicated and uncomplicated UTIs are uropathogenic E. coli strains (UPECs) (about 80\% of cases) (Foxman, 2014; FloresMireles et al., 2015). UPEC encodes many virulence factors required at various stages of UTI pathogenesis, including adherence and colonization, invasion and persistence, biofilm development, formation of intracellular bacterial communities (IBCs) and quiescent intracellular reservoirs (QIRs), kidney colonization and epithelial damage. However, the most important stage during UTI pathogenesis is bacterial adherence and colonization of the host cells and tissues (Flores-Mireles et al., 2015).

Many UPECs initiate infection using pili or fimbrial appendages belonging to the surface-exposed polymeric adhesive structures whose biogenesis in Gram negative bacteria is driven via the highly conserved chaperoneusher pathway (CUP). Among these adhesive factors, the most dominant are pili type 1 and $\mathrm{P}$ (functioning as the monoadhesins) and Dr/Afa family of polyadhesins. Genes required for the bioassembly of pili/fimbriae are located in the CUP pilus operons (e.g. fim, pap, dra, afa) with conserved genetic organization. The above polymeric structures are often capped with various adhesins responsible for the recognition of different receptors coating the surface of epithelium within the lower and upper urinary tract. Such bacterial interactions with receptors can be used to mediate a distinct tissue tropism (Thanassi et al., 1998; Soto \& Hultgren, 1999; Zavialov et al., 2007; Terlizzi et al., 2017). Thus, the tip FimH adhesin of type 1 pili enables $\mathrm{fim}^{+} \mathrm{E}$. coli to cause cystitis by binding the mannosylated receptors of the bladder epithelium (Sokurenko et al., 1997; Spaulding et al., 2108). In turn, the PapG of $\mathrm{P}$ pili adhesin, recognizing globosides in the kidneys, allows the pap ${ }^{+} E$. coli strains to develop pyelonephritis (Leffler \& Svanborg-Edén, 1981; Roberts et al., 1994; Dodson et al., 2001). Importantly, E. coli strains harboring Dr/Afa adhesins (dra/afa) which recognize a decay-accelerating factor (DAF) as the main 
receptor, cause pyelonephritis (30\%), cystitis (30-50\%), chronic diarrhea in children $(10-15 \%)$, and recurrent infections in young women $(50 \%)$. These strains are also a significant problem for pregnant women during the third trimester of pregnancy, mainly because they are responsible for $40 \%$ of cases of pyelonephritis (Nowicki et al., 1984; Nowicki et al., 1994; Goluszko et al., 1997; Goluszko et al., 2001).

Antibiotic therapy of UTIs is effective in many cases (Terlizzi et al., 2017; Giancola et al., 2017). However, an increasing number of antibiotic resistant UPECs is still observed worldwide. A good example is the increase in resistance to fluoroquinolines among UPECs to around $50 \%$ in the European countries, and even up to $70 \%$ in China, India and Vietnam (Zowawi et al., 2015). In case of women (especially during pregnancy) suffering from UTI recurrences, the increment of UPEC strains resistant to ampicillin $(96.42 \%)$, tetracycline $(85.7 \%)$, amikacin (71.42), ciprofloxacin (67.85\%) and gentamycin (58.71\%) is also observed (Habibi \& Khameneie, 2016). In addition, a broad spectrum of antibiotics has limited utility in long-term therapy (Zowawi et al., 2015). Due to the alarming and rapid overgrowth of antibiotic resistance among UPECs, there is a need to develop new, alternative and specific forms of UTI treatment and prophylaxis. Here, we briefly reviewed the most promising innovative methods and strategies for therapy and prevention of UTIs caused by UPECs (Table 1).

\section{VACCINES BASED ON ADHESINS AND BACTERIAL EXTRACTS}

In the light of increasing resistance of uropathogens to antibiotics, alternation of physiological gut microbiota during treatment, allergic reactions to standard antibacterial medicaments and difficulties in prevention or limita- tion of UTI recurrences, there is a need to develop novel remedies to fight them. Therefore, it can be assumed that vaccines are a promising tool for preventing UTIs caused by UPECs in humans. The design and preparation of vaccines are based on different strategies, including key virulence factors and pathogenicity mechanisms of UPECs (Foxman, 2014; Flores-Mireles et al., 2015).

\section{Pili and fimbrial adhesins}

Bacterial adherence mediated by the highly organized adhesive systems such as pili or fimbriae is a key stage in the pathogenesis of UTIs (Flores-Mireles et al., 2015). Therefore, Gram-negative bacterial adhesins, especially those assembled via the conserved CUP, and adherence itself represent an excellent target for potential vaccine candidates. Characteristic features of the surface-exposed adhesins, as the structural and functional elements of the linear homopolymers (polyadhesive fimbriae) or heteropolymers (monoadhesive pili/fimbriae), are prone to antigenic diversity and amino acid sequence variability and thus are used by pathogens as defense mechanisms against immune response of the infected organism ( $\mathrm{Za}-$ vialov et al., 2007; Zav'yalov et al., 2010; Werneburg \& Thanassi, 2018). Polyadhesins mainly consist of only one adhesive subunit that occurs in hundreds of copies within the whole core of the fimbrial structure. However, monoadhesins are composed of up to seven different subunits and in comparison to polyadhesive fimbriae, they are tipped with only one adhesive subunit; this is important for the design and synthesis of vaccines, especially the chimeric ones (Hung et al., 1996; Thanassi et al., 1998; Soto \& Hultgren, 1999; Remaut et al., 2006, 2008; Zavialov et al., 2007; Fronzes et al., 2008; Waksman \& Hultgren, 2009).

Generally two therapeutic strategies dominate, one based on the bacterial adherence and the other on ad-

Table 1. Alternative therapeutic and preventive strategies to fight UTIs.

\begin{tabular}{|c|c|c|c|}
\hline $\begin{array}{l}\text { Type of UTI treatment/ } \\
\text { prevention }\end{array}$ & Therapeutic components & Biological effect & References \\
\hline \multirow{6}{*}{ Vaccines } & $\begin{array}{l}\text { Native or chimeric pili/fim- } \\
\text { briae and adhesins of CUP }\end{array}$ & \multirow{3}{*}{$\begin{array}{l}\text { Reduction in bacterial adhe- } \\
\text { sion and colonization }\end{array}$} & $\begin{array}{l}\text { Asadi et al., 2013; Goluszko et al., 2005; } \\
\text { Roberts et al., 1984; Zalewska et al., 2003, } \\
\text { 2007; Savar et al., } 2014\end{array}$ \\
\hline & $\begin{array}{l}\text { Chaperone-adhesin com- } \\
\text { plexes }\end{array}$ & & $\begin{array}{l}\text { Langermann et al., 1997, 2000; Roberts et } \\
\text { al., 2004; Spaudling \& Hultgren, } 2016\end{array}$ \\
\hline & $\begin{array}{l}\text { Killed uropathogens } \\
\text { (Solco Urovac, Uro Vaxom) }\end{array}$ & & $\begin{array}{l}\text { Beerepoot, 2013; Kochiashvili et al., 2014; } \\
\text { Naber, 2009; Neto et al., 2016; Wolski et al., } \\
2017\end{array}$ \\
\hline & $\begin{array}{l}\text { Asymptomatic bacteriuria } \\
\text { isolates }\end{array}$ & $\begin{array}{l}\text { Interference with bladder colo- } \\
\text { nization by uropathogens }\end{array}$ & O’Brien et al., 2018; Stork et al., 2018 \\
\hline & Toxins and proteases & $\begin{array}{l}\text { Protection of the host tissues } \\
\text { from bacterial damage }\end{array}$ & O'Hanley et al., 1991; Sivick \& Mobley, 2010 \\
\hline & Siderophores & $\begin{array}{l}\text { Inhibition of iron acquisition } \\
\text { systems and reduction in bac- } \\
\text { terial colonization }\end{array}$ & $\begin{array}{l}\text { Alteri et al., 2009; Brumbangh et al., 2013; } \\
\text { Mike et al., 2016; Russo et al., } 2003\end{array}$ \\
\hline \multirow{3}{*}{$\begin{array}{l}\text { Small inhibitory com- } \\
\text { pounds }\end{array}$} & $\begin{array}{l}\text { Receptor analogues: man- } \\
\text { nosides, galactosides, gly- } \\
\text { codendrimers, galactosides, } \\
\text { galactosaminosides }\end{array}$ & $\begin{array}{l}\text { Blocking of bacterial adher- } \\
\text { ence }\end{array}$ & $\begin{array}{l}\text { Brumbaugh \& Mobley, 2012; Conover et } \\
\text { al., 2016; Cusumano et al., 2011; Guiton et } \\
\text { al., 2012; } \\
\text { Han et al., 2010, 2012; Hu et al., 2016; Mo- } \\
\text { usavifar et al., 2018 }\end{array}$ \\
\hline & $\begin{array}{l}\text { Derivatives of 2-pyridone: } \\
\text { pilicides }\end{array}$ & \multirow[t]{2}{*}{$\begin{array}{l}\text { Inhibition of CU pili/fimbriae } \\
\text { or curli biogenesis }\end{array}$} & $\begin{array}{l}\text { Chorell et al., 2010; Dang et al., 2014; Green } \\
\text { et al., } 2014 \text {; Piątek et al., 2013; Svennson et } \\
\text { al., } 2001\end{array}$ \\
\hline & Curlicides & & Cegelski et al., 2009; Chorell et al., 2011 \\
\hline Phage therapy & Bacteriophages & Lysis of uropathogens & $\begin{array}{l}\text { Leitner et al., 2017; Sybesma et al., 2016; } \\
\text { Ujmajuridze et al., } 2018\end{array}$ \\
\hline
\end{tabular}


hesive proteins. The first approach is associated with isolated pili or fimbrial fractions, by using their strong immunogenic properties and their presence on the surface of bacterial cells in a large number of copies $(\sim 500$ copies per cell) (Klemm \& Schembri, 2000). Investigations carried out with a mouse model (C3H/Hej) had shown that vaccination with purified wild type Dr fimbriae (of E. coli $\mathrm{Dr}^{+} \mathrm{IH} 11128$ ) induced an excellent humoral response leading to the production of specific serum antibodies. Additionally, antibody production (as a result of a post-vaccination response) protected animals that underwent experimental UTI from increased mortality but did not decrease colonization of the bladder and kidney (Goluszko et al., 2005).

The second strategy is based on the adhesin-chaperone complexes. Experimental studies with mouse and cynomolgus monkey models of UTIs using PapD chaperone-PapG adhesin or FimC chaperone-FimH adhesin protein complexes, confirmed a high efficacy in inhibiting host-pathogen interactions of adhesion vaccines of this type, and thus their protective function against UTIs (such as pyelonephritis or cystitis) (Langermann et al., 1997; Langermann et al., 2000; Roberts et al., 2004; Asadi et al., 2013; Savar et al., 2014). The potential use of PapD-PapG and FimC-FimH interactions in vaccine development was largely associated with the production of antibodies against FimH and PapG (blocking the function of FimH and FimG adhesins, respectively) during bacterial colonization of the bladder or kidneys (Roberts et al., 1984; Roberts et al., 2004; Langermann et al., 1997; Langermann et al., 2000). The purpose of current research is to modify the FimC-FimH based vaccine to make it a better stimulator of cellular and humoral immune response in the immunized host (Asadi et al., 2013; Savar et al., 2014). One possibility is to obtain a fusion protein composed of a FimH adhesin and a FliC flagellin in order to stimulate an acute inflammatory response associated with the Toll-like receptor 4 (TLR4) signaling cascade (Valore et al., 1998; Savar et al., 2014). TLR4 activity is associated with production of bactericidal peptides (mainly $\beta$-defensin-1 and cathelicidin) by epithelial cells that leads to the destruction of bacteria (Chromek et al., 2006; Nielsen et al., 2014). In January 2014, a first phase of clinical human studies was started to assess the usefulness of immunization with the FimC-FimH vaccine containing a synthetic monophosphoryl lipid A analogue as an adjuvant (Spaudling \& Hultgren, 2016).

Another possibility of using pili/fimbriae in the context of a potential vaccine is their application as the carriers of heterologous antigenic determinants of bacterial or viral origin. A very serious limitation of this strategy is the size of the epitope used, which should not affect the structure of adhesive subunit (carrier) and interfere with bioassembly of adhesive hetero- or homoassociates into a complete pili/fimbrial structure (on the surface of bacterial cells) (Klemm \& Schembri, 2000). A good example of this approach are homopolymeric Dr fimbriae (consisting of hundreds of repeating DraE adhesive subunits) of uropathogenic E. coli $\mathrm{Dr}^{+}$, which were applied as a carrier of a model antigenic determinant of glycoprotein $\mathrm{D}$ derived from the Herpes simplex virus type 1 (HSV-1). Insertion of a heterologous epitope included the N-terminal region of the surface-exposed domain 2 within the DraE fimbrial subunit which is responsible for the invasive properties of bacterial cells (Das et al., 2005). In this region of the DraE adhesin, the selected antigenic determinants can be inserted without interfering with the fimbriae biogenesis, which determines the display and am- plification of a given epitope (in thousands of copies per bacterial cell) in the form of polyadhesive homopolymers on the surface of bacteria. Immunogenicity of the DrHSV chimeric fimbriae was determined by immunization of rabbits in which a protective immune response was stimulated leading to the production of antibodies specific for both, the DraE adhesin and the HSV epitope (Zalewska et al., 2003). All analyses highlight the high efficacy of chimeric Dr fimbriae as the vaccine candidate against UTIs and other diseases, depending on the inserted antigenic determinant (Zalewska et al., 2007).

\section{Uropathogenic and asymptomatic bacteriuria $E$. coli}

Other therapeutic strategies against UTIs involve inactivated vaccines based on the whole bacterial cells containing "killed" microorganisms and live (attenuated) vaccines containing viable ("live") microorganisms with weakened pathogenic properties obtained by reducing virulence of selected pathogens. Due to the possibility of reversion of the attenuated strains to their virulent forms, the inactivated vaccines may be more important for the prevention of UTIs in humans. From this group of vaccines, Solco Urovac is already available on the market. This bacterial vaccine is a lyophilisate consisting of six heat-killed uropathogenic E. coli (classified into different serotypes) and selected strains of Proteus mirabilis, Klebsiella pneumoniae, Enterococcus faecalis and Morganella morganii. Clinical studies revealed high efficacy of Solco Urovac and thus it was approved for administering for vaginal suppository use in the treatment and prevention of recurrent UTIs of bacterial origin in women. Therefore, Solco Urovac seems to be the most promising alternative to standard antibiotics used during UTI therapies (Kochiashvili et al., 2014; O’Brien et al., 2018).

Among current therapeutic strategies, there is also an immunostimulant OM-89 substance known in Europe as Uro Vaxom and distributed by EurimPharm GmbH pharmaceutical company (Neto et al., 2016). Om-89 is a lyophilized bacterial lysate of 18 strains of uropathogeic E. coli most often responsible for UTIs. In 2008, European Society of Urology recommended the use of OM-89 to prevent uncomplicated UTIs in women. Uro Vaxom may also provide supportive therapy in cases of recurrent and chronic UTIs caused by the UPEC strains (cystitis, pyelonephritis, urethritis, bladder infections and ureters after catheterization) (Neto et al., 2016). In Poland, Uro Vaxom is used for treating acute uncomplicated UTIs in adults and children over 4 years old in combination with antibiotic therapy and as a prophylactic regimen to prevent recurrent infections of the lower urinary tract (Wolski et al., 2017). The efficacy of Uro Vaxom has been also confirmed in treatment and prevention of UTIs in patients after renal transplantation. This immunotherapeutic formulation may also have the desired effect in people with neurogenic bladder dysfunction and undergoing catheterization (Naber, 2009; Beerepoot, 2013; Wolski et al., 2017).

Recent studies have been focused on the strains of E. coli (with reduced virulence) responsible for asymptomatic bacteriuria (ABU) to prevent the occurrence of symptomatic, chronic or recurrent urinary tract infections in humans. This approach is based on the mechanism of bacterial interference (after asymptomatic colonization of the bladder) with uropathogens (Stork et al., 2018). Bacterial interference is a promising alternative to the classic antibiotic therapy used during UTI treatment, and its main aim is to prevent colonization of the bladder by invading uropathogens. The key point in this 
therapy is a selected strain of E. coli (ABU model isolate 83972) which is not able to express type 1 and $\mathrm{P}$ pili, and F1C fimbriae. A specific feature of this strain is faster rate of colonization of the bladder through the planktonic growth or biofilm development when compared to uropathogens. This in turn results in long-term therapeutic persistence of $\mathrm{ABU}$ bacteria in the urinary tract without significant symptoms and pathology, and the recurrent and symptomatic UTIs prevention (O'Brien et al., 2018; Stork et al., 2018). Current investigations have also contributed to the identification of three other ABU strains (isolates 61, 106 and 123) effectively interfering with colonization of the model ABU isolate 83972. In addition, these $\mathrm{ABU}$ isolates were characterized by low in vivo virulence, lack of marked cytotoxic activity and susceptibility to antibiotic therapy. The studies were based on a mouse model of sepsis. Therefore, the above ABU strains represent an alternative therapeutic and preventive tool (to ABU model strain 83972) against uropathogens that can function as a safe, asymptomatic competitor of the bladder colonization (Stork et al., 2018).

Importantly, further examinations are still required to select a universal vaccine target (not affecting intestinal commensal microflora) that could be an alternative to the antibiotic-based prophylactic regimens in women with recurrent UTIs.

\section{VACCINES BASED ON BACTERIAL SIDEROPHORES, TOXINS AND PROTEASES}

Systems involved in bacterial ferric uptake seem to be a novel promising target for the preparation of vaccines targeting uropathogenic strains which use iron ions as a factor necessary for bacterial colonization and their survival in the urinary tract environment which is deficient in nutrients (Garcia et al., 2011; Brumbangh et al., 2013). Generally, these types of vaccines are based on the ferric chelators responsible for the transport of bound iron ions into the bacterial cell (such as FyuA, yersiniabactin ferric uptake receptor, IutA, aerobactin iron transport receptor, IreA, siderophore receptor iron-responsive element, IroN, iron uptake receptor) and systems used to acquire a haem group by bacteria (Hma, haem acquisition protein) (Brumbangh et al., 2013). Universally, vaccination of the tested animals with iron receptors induced protective immunity in experimental models of UTIs (Mike et al., 2016). Therefore, immunization of mice with FyuA receptor and Hma protein had shown their preventive role against pyelonephritis. In turn, immunization with IutA and IreA resulted in reduced of colonization of the mouse bladder by bacteria (Alteri et al., 2009; Brumbaugh et al., 2013). Additionally, protective function of the IroN receptor against experimental UTI was stimulated in the rat model. In this case, a specific humoral response against the receptor was elicited (Russo et al., 2003). Success of these experimental studies in animal models emphasizes the important role of selected siderophores as an alternative treatment of UTIs in humans.

Another potential targets for the rational vaccine design and development can be proteases and toxins which play an important role in the pathogenesis of UTIs. This group of vaccines includes toxoids and recombinant vaccines (Flores-Mireles et al., 2015). Toxoids are purified and inactivated bacterial metabolites - toxins, with the ability to stimulate an immune response associated with the production of specific antibodies. Haemolysin (HlyA) which is a UPEC pore-forming cytolysin destabilizing the host cell membranes, arises the greatest interest in the vaccine context (Dhakal \& Mulvey, 2012). Immunization of mice with HlyA contributed to reduction in renal scarring, but did not provide protection against renal colonization by UPEC strains (O'Hanley et al., 1991; Sivick \& Mobley, 2010). Therefore, further studies of these types of vaccines are required for the development of useful therapeutic strategies.

\section{SMALL COMPOUNDS INHIBITING BACTERIAL ADHERENCE}

Detailed studies of machinery driving the biogenesis of pili/fimbriae via the classical chaperone/usher secretory pathway in Gram-negative bacteria, as well as bacterial adhesion based on the interactions with the host receptors, allowed to design two classes of compounds. The first group of such potential antivirulence therapeutics inhibits biological functions of surface-exposed adhesive appendages and the second one blocks their bioassembly on the surface of bacterial cells (Pinkner et al., 2006; Cusumano et al., 2011; Piątek et al., 2013; Dang et al., 2014).

\section{Mannosides and galactosides}

The first strategy for protection against UTIs is based on the compounds inhibiting bacterial adherence by blocking the function of pili/fimbriae, and the subsequent stages of uropathogenesis, including: bacterial colonization, invasion and formation of intracellular bacterial communities (IBCs) (Pinkner et al., 2006; Cusumano et al., 2011; Piatek et al., 2013; Dang et al., 2014). Additionally, in comparison to treatment of UTIs with antibiotics (carrying the risk of development of bacterial resistance) the antiadhesion therapy does not generate selective pressure and induction of mutations in the adhesive subunits (Tomašić et al., 2014).

A good example of compounds of this type are mannosides, the diarylated derivatives of mannose readily reaching the bloodstream, that are low-molecular weight molecules and analogues of a cellular receptor recognized and bound by uropathogens. These compounds have the ability to block the adherence of bacteria to epithelial cells mediated by FimH adhesin functioning as the tip subunit of type 1 pili (of E. coli fim ${ }^{+}$) (Han et al., 2010; Han et al., 2012; Cusumano et al., 2011, Klein et al., 2010). The FimH receptor-binding lectin domain recognizes the mannose epitopes and mannoside glycans conjugated with the host receptor of uroplakin Ia, that coats the surface of umbrella urothelial cells lining the urethra and bladder. Therefore, the action of monovalent mannosides is based on the binding of FimH adhesin and blocking bacterial adherence to mannosylated cell receptors (Han et al., 2010; Kleeb et al., 2015; Sauer et al., 2016).

D-mannose plays an important role in the human metabolic processes and post-translation modifications of some proteins by glycosylation (Gordon, 2000). In addition, like mannosides, D-mannose blocks the binding of FimH adhesin to mannosylated receptors, but the inhibition of the lectin pocket mediated by mannosides is 1000000 -fold greater, which increases their potential therapeutic role (Bouckaert et al., 2005; Han et al., 2010). The use of D-mannose as a dietary supplement also improves the health condition of humans receiving it ( $\mathrm{Hu}$ et al., 2016). Therefore, the X-ray crystal structures of the FimH bound to $\alpha$-D-mannose or its derivatives and the structural data concerning conformational conversion (between an elongated - mannose binding or compact 
form) of the FimH lectin domain were the most important for the rational design and synthesis of mannosides as the bacterial FimH antagonists (Han et al., 2012; Sauer et al., 2016).

The activity of mannosides as FimH monovalent inhibitors and orally bioavailable therapeutic agents has been confirmed with mouse models (Cusumano et al., 2011; Han et al., 2012). These animal studies highlighted the role of mannosides as the original therapeutic strategy against UTIs, catheter-associated infections (CAUTIs), and also multi-drug resistant UPECs by decreasing the antibiotic resistance rate (Guiton et al., 2012; Cusumano et al., 2011; Totsika et al., 2013; Kostakioti et al., 2012). It is also possible to combine mannosides with the PapG adhesin antagonists which are galabiose-based inhibitors causing a reduction in adherence of uropathogenic Pand type 1-piliated E. coli strains that contain both, the pap and fim gene clusters (Brumbaugh \& Mobley, 2012; O’Brien et al., 2018).

Currently, scientific interests are focused around multifunctional inhibitors, such as glycodendrimers with high affinity to leguminous, bacterial, and mammalian lectins (Touaibia et al., 2007; Lindhorst et al., 2010; Cecioni et al., 2015; Mousavifar et al., 2018). In comparison to monovalent mannosides, multivalent compounds possess several copies of mannoside branching residues as the ideal target for blocking bacterial adherence, mediated by the FimH subunit, and hence infection. However, further studies concerning the pharmacokinetic properties of glycodendrimers are needed for their future use as the potential FimH multivalent antagonists of UPECs (Mousavifar et al., 2018).

The newest group of FimH antagonists consists of modified and optimized ortho-biphenyl galactosides and galactosaminosides with increased potency. This is related to the fact that besides mannose, FimH adhesin binds terminal galactose $(\mathrm{Gal})$ and $\mathrm{N}$-acetylgalactosamine (GalNAc) residues in the core-1 and -2 O-glycans decorating glycoproteins in the bladder. The adhesive subunit capping the tip of type 1 pili is also able to recognize the Thomsen-Friedenreich (TF) antigen (Galß1-3GalNAc) on the kidney epithelium, which contributes to kidney infections. These compounds represent low molecular-weight glycomimetics with increased inhibitory activity when compared to the initial lead GalNAc 1. Such compounds can be potentially used after further optimization for potential treatment and prevention of chronic UTIs via blocking the bacterial FimH binding to the inflamed kidney and bladder tissues (Conover et al., 2016, Maddirala et al., 2018).

\section{Pilicides}

The second group of novel compounds for UTI treatment includes pilicides, derivatives of the ringfused-2-pyridone which are small molecules inhibiting the bioassembly of mono- and polyadhesive structures of the CUP (Aberg \& Almqvist, 2007). These innovative compounds can be a promising alternative to commonly used antibiotics and therapeutics in the treatment of UTIs. Pilicides were originally designed and described as compounds that inhibit biogenesis of type 1 pili of UPEC fim ${ }^{+}$(Pinkner et al., 2006; Svennson et al., 2001).

The action of these compounds is targeted to periplasmic chaperones (FimC and PapD, encoded by the fim and pap operons, respectively) of the CUP due to the high degree of sequence and structure conservation. Preliminary studies based on the crystal structure of PapD chaperone protein bound to the C-terminal peptide of the PapG adhesin, allowed to identify the potential region of interaction between pilicide (mimicking the donor strand of PapG) and the chaperone. This region includes a conserved R8(Arg)-K12(Lys) motif of a positively charged anchor within a large cleft between both, the $\mathrm{N}$ and C-terminal domains of the chaperone (Svensson et al., 2001; Pinkner et al., 2006; Aberg \& Almqvist, 2007; Chorell et al., 2010). Further examinations using the PapD-PapK and pilicide-PapD crystal structures had shown the presence of a second region covering the F1-G1 loop outside the cleft of the chaperone. This region is required for the activity of pilicide by preventing binding of the chaperone-pilus subunit complexes to the usher via a reaction of donor strand exchange, DSE, and thus disrupting bioassembly of pili. However, interaction of pilicide with the F1-G1 region did not interfere with formation of the chaperone-pilus subunit complex through a donor strand complementation (DSC) mechanism. Ultimately, the action of these compounds resulted in the inhibition of type 1 or $\mathrm{P}$ piliation on the surface of bacterial cells and thus the decrease in adherent properties of bacteria. In this situation, unbound bacteria could be effectively washed out of the urinary tract by the flow of urine during micturition (Pinkner et al., 2006).

Studies based on pilicides indicate a broad-spectrum activity of such compounds in relation to the pili/fimbriae bioassembled via the CUP (Greene et al., 2014). Distribution of the CU system in a wide-range of Gramnegative bacteria additionally confirms their usefulness. For example, a single species of UPEC may contain up to 16 genetically complete CUP gene clusters (Wurpel et al., 2013). Importantly, in UPEC strains possessing multiple CUP operons, gene expression is strictly controlled. Therefore, at a certain time, a single UPEC cell is able to expresses only one type of the CUP pili (Nowicki et al., 1984).

A modification of the pilicides by a substituent at position 2 (e.g., aryl group) in combination with a substituent at position 8 (e.g., cyclopropyl group) resulted in compounds which had reduced hemagglutination and biofilm development mediated by E. coli $\mathrm{fim}^{+}$or $\mathrm{pap}^{+}$ very efficiently. The observed effect was associated with a decrease in the surface level of type 1 or $\mathrm{P}$ piliation, respectively (Aberg et al., 2005; Aberg et al., 2007; Cegelski et al., 2009; Pinkner et al., 2006; Chorell et al., 2010; Dang et al., 2014).

Further studies have shown that other derivatives of 2-pyridone (with a substituent of $\mathrm{CH} 2-1$-naphthyl at $\mathrm{C} 7$ and cyclopropyl or phenyl at C8, respectively) decreased the expression level of Dr fimbriae on the surface of bacterial cells by blocking the CUP and thus reducing the adherence of E. coli $\mathrm{Dr}^{+}$strains (an etiologic agent of pyelonephritis in humans and mice) to epithelial cells (Piatek et al., 2013).

Recent studies revealed that ring-fused 2-pyridone ec240 pilicide was able to reduce the motility of flagella and interfere with regulation of the $\mathrm{CU}$ system, driving the assembly of surface-exposed type 1 and $P$ pili, and $S$ fimbriae, often encoded by UPEC. Examinations based on the E. coli UTI89 model strain of cystitis indicated a significant effect of the analyzed compound on the type 1 pilus expression. Gene expression of the fim operon is regulated by a fims promoter element, a reversible DNA segment which can oscillate between two orientations: phase on and phase off. The action of ec 240 was associated with the induction of fims phase off orientation and increasing the level of S-fimbrial transcription regulators 
of SfaB and SfaX, and the P-pilus PapB regulator (which also promotes fims phase off) (Green et al., 2014).

Additional experimental studies had also shown good efficacy of pilicides in disrupting pilus bioassembly in Haemophilus influenza and Klebsiella pneumonia, highlighting their broad spectrum of activity (Kline et al., 2010; Flores-Mireles et al., 2015).

\section{Curlicides}

Another group of potential therapeutic agents is represented by curlicides which are peptide mimetic compounds exhibiting pilicide-like activity. Curli (amyloid-like aggregation fibres) are surface-exposed, long, elastic adhesive filaments with the ability to interact with host glycoproteins and stimulate autoaggregation of bacterial cells. Thus, these amyloid fibres enable biofilm formation and survival of bacteria in the external environment (Goyal et al., 2014). They also exhibit a typical structure and physical characteristics of the amyloid fibrils observed in the course of some human degenerative diseases, but they do not the result from misfolding of the proteins (Chapman et al., 2002; Wang et al., 2007; Dueholm et al., 2011).

Curli are composed of CsgA subunits (curlin) that are the major component of the fibers. The $\mathrm{CsgB}$ protein (the minor curli subunit) is bound to the cell surface and acts as the initiator of the extracellular polymerization of CsgA subunits forming curli with a helical configuration. Both proteins are synthesized in the form of precursors with Sec signal sequences and their secretion at the surface of bacterial cells is dependent on soluble accessory factors, such as $\mathrm{CsgE} / \mathrm{CsgF}$ and $\mathrm{CsgG}$ lipoprotein, that form an oligomeric curli-translocation channel in the outer membrane (Loferer et al., 1997; Robinson et al., 2006; Nenninger et al., 2009; Goyal et al., 2014). In the UPEC strains, the assembly of curli requires proteins encoded by two operons, csgDEFG and $\operatorname{csg} A B C$ (curli specific genes $B A C$ ) located next to each other but transcribed independently. The proteins encoded by the $\operatorname{csg} D E F G$ operon allow the extracellular translocation of CsgA subunits and coordinate formation of surface-exposed adhesion structures. In turn, the $\mathrm{Csg} B$ protein of the $\operatorname{csg} A B C$ operon is essential for nucleation and incorporation of CsgA self-assembling subunits into a growing amyloidlike fiber, whereas $\mathrm{CsgC}$ is an oxidoreductase whose function is unknown (Hammar et al., 1996; Bian et al., 1997; Chapman et al., 2002; Barnhart \& Chapman, 2006).

Similarly to pilicides, curlicides are bioassembly inhibitors of type 1 pili and curli fibers. Therefore, they provide protection against $A \beta$ aggregation and formation of amyloid appendages on the surface of bacterial cells (Chorell $e t$ al., 2011). Studies based on the mouse cystitis model have demonstrated the effectiveness of low molecular curlicide FN075 in inhibition of the type 1 pili production and biogenesis of amyloids by UPEC strains. Ultimately, this compound is also able to reduce the formation of biofilm by bacteria and their virulent properties (Cegelski et al., 2009).

Although the results obtained are promising, further research is needed, especially with the mouse models of UTIs to determine the role of the above compounds in the infections caused by Gram-negative bacteria and evaluate the efficacy and bioavailability of both, the pilicides and curlicides, as the potent innovative therapeutic agents.

\section{BACTERIOPHAGE THERAPY}

Due to increasing and continuing resistance of uropathogens to commonly used antibiotics worldwide, bacteriophages seem to be an excellent, alternative therapy in treating patients suffering from UTIs. It is also possible to combine phagotherapy with antibiotic therapy to increase the effectiveness of treatment. Currently, phage therapy functions as a registered medicine in several countries of Eastern Europe, including Georgia, Ukraine, Armenia and Russia (Abedon et al., 2011; Chanishvili, 2012; European Centre for Disease et al., 2017; Leitner et al., 2017). In the Western world, the use of phage therapy against various bacterial infections has not been approved by regulatory authorities. There is also no legal basis for the use of this type of treatment or even requirements regarding its safety and quality (Pirnay et al., 2011; Pirnay et al., 2015).

The mechanism of bacterial antibiotic resistance differs from the mechanism of resistance to bacteriophages. In comparison to antibiotics, bacteriophages have many advantages, such as self-replication, self-evolution and display a selective bactericidal activity in vivo and in vitro (without affecting the physiological bacterial microflora). Although the lytic activity of bacteriophages has been repeatedly tested as a therapy against various infections caused by antibiotic-resistant bacteria, applications of bacteriophages in the treatment of UTI are uncommon (Arshba \& Bagdoeva, 1965, Danilova, 1996; Letkiewicz et al., 2010; Chanishvili, 2012). The main limitation of phage therapy is the low number of studied patients, lack of randomized, placebo-controlled studies and deficiency in double-blind randomized control trials that are performed in accordance with Western standards (Collins \& MacMahon, 2001; Chanishvili, 2012; Ujmajuridze et al., 2018). However, it should be taken into account that clinical, non-randomized observational studies are also credible and have high value as randomized trails (MacMahon \& Collins, 2001; Vandenbroucke, 2004).

The efficacy and safety of bacteriophage therapy was demonstrated for treating UTIs in patients with transurethral resection of prostate and after kidney transplantation to prolong the survival of the allograft, catheter associated UTIs and urosepsis (Gorski et al., 2003a, b; Weber-Dabrowska et al., 2003; Nicolle et al., 2005; Hooton et al., 2010; Leitner et al., 2017; Bonkat et al., 2018; Ujmajuridze et al., 2018). During treatment, after exceeding the threshold dose, bacteriophages were found in the urine and it did not cause their inactivation. In addition, histopathological examination of the kidneys and bladder did not show any pathological changes associated with administration of phages. Very often, antibiotic sensitivity or resistance of bacteria were not correlated with the phages tested. Thus, the bacterial strain could be resistant to all tested antibiotics but susceptible to all bacteriophages. On the other hand, the strain could be sensitive to certain antibiotics and resistant to all studied bacteriophages (Weber-Dąbrowska et al., 1987; Perepanova et al., 1995; Sybesma et al., 2016; Leitner et al., 2017; Ujmajuridze et al., 2018). All of these data indicate that phages may be present at relatively high concentrations, without harmful effect in the urinary tract, within which they can constitute a local anti-bacterial defense against invading uropathogens. Despite many successes associated with phagotherapy, its effectiveness and safety during treatment, further research is required to finally verify and apply this method for common therapy and prevention of UTIs in the Western word.

\section{CONCLUSIONS}

UTIs are one of the most common microbial infections affecting millions of people annually. The most serious problem with infections of this type are chronicity 
and recurrences entailing huge costs from state budgets for the treatment of UTIs and complications associated with them worldwide. An additional problem is the continuously increasing resistance of uropathogens to commonly used antibiotics resulting from the need to repeat antibiotic therapy in case of recurring or chronic episodes of infection and also from the usual abuse of antibiotics (Stamm \& Norrby 2001; Foxman et al., 2002; Guglietta, 2017).

The major etiologic factor of complicated and uncomplicated UTIs are UPECs which account for $65 \%$ and $75 \%$ cases of infection, respectively. Up to $68 \%$ of recurring UTIs are caused by UPECs (identical to the original strain) within one year of the initial infection. UPECs are also currently the most common cause of hospital-associated infections (Foxman, 2014; FloresMireles et al., 2015; Guglietta, 2017).

The conventionally recommended antibiotic therapy for UTIs (typically with trimethoprim, sulfamethoxazole, ciprofloxacin and ampicillin) is effective (Foxman, 2010; Kostakioti et al., 2012). However, the increasing threat of antibiotic resistance mechanisms among uropathogens creates the need to develop alternative forms of treatment and prophylaxis of UTIs which would allow to reduce the suffering and improve the quality of life of afflicted persons. The targets of such antivirulence therapies, including the key virulence determinants of pathogens, differ from those used in conventional antibiotic therapy. Novel approaches are also responsible for pathogen neutralization and host protection from the disease. In this context, new therapeutic strategies and mechanisms (such as vaccines, receptor analogues, pilicides/ curlicides, bacterial competitors or phagotherapy) based on the processes important during UTI pathogenesis, appear to be the most promising.

\section{Conflict of interest statement}

The Authors declare no conflict of interest

\section{REFERENCES}

Abedon ST, Kuhl SJ, Blasdel BG, Kutter EM (2011) Phage treatment of human in fections. Bacteriophage 1: 66-85. https://doi, org/10.4161/bact.1.2.15845

Åberg V, Almqvist F (2007) Pilicides-small molecules targeting bacterial virulence. Org Biomogl Chem 5: 1827-1834. https://doi.org/10.1039/ b702397a

Aberg V, Fällman E, Axner O, Uhlin BE, Hultgren SJ, Almqvist F (2007) Pilicides regulate pili expression in E. coli without affecting the functional properties of the pilus rod. Mol Biosyst 3: 214-218. https://doi.org/10.1039/b613441f

Aberg V, Hedenström M, Pinkner JS, Hultgren SJ, Almqvist F (2005) C-Terminal properties are important for ring-fused 2-pyridones that interfere with the chaperone function in uropathogenic E. coli. Org Biomol Chem 3: 3886-3892. https://doi.org/10.1039/b509376g

Alteri CJ, Hagan EC, Sivick KE, Smith SN, Mobley HL (2009) Mucosal immunization with iron receptor antigens protects against urinary tract infection. PLoS Pathog 5: e1000586. https://doi. org/10.1371/journal.ppat.1000586

Arshba C, Bagdoeva K (1965) Application of phagetherapy against colibacterial infections of urinary tract. Clin Exp Urol 3: 7-13

Asadi Karam MR, Oloomi M, Mahdavi M, Habibi M, Bouzari S (2013) Vaccination with recombinant FimH fused with flagellin enhances cellular and humoral immunity against urinary tract infection in mice. Vaccine 31: 1210-1216. https://doi.org/10.1016/j.vaccine.2012.12.059

Barnhart MM, Chapman MR (2006) Curli biogenesis and function. Annu Rev Microbiol 60: 131-147. https://doi.org/10.1146/annurev. micro.60.080805.142106

Beerepoot MA, Geerlings SE, van Haarst EP, van Charante NM, ter Riet G (2013) Nonantibiotic prophylaxis for recurrent urinary tract infections: a systematic review and meta-analysis of randomized controlled trials. J Urol 190: 1981-1989. https://doi.org/10.1016/j. juro.2013.04.142
Bian Z, Normark S (1997) Nucleator function of CsgB for the assembly of adhesive surface organelles in Escherichia coli. EMBO J 16: 5827-5836. https://doi.org/10.1093/emboj/16.19.5827

Bonkat, G, Pickard R, Bartoletti R, Cai T, Bruyère F, Geerlings SE, Wagenlehner F, Wullt B. Guidelines Associates: T. Cai , B. Köves, A. Pilatz, B. Pradere, R. Veeratterapillay (2018) European Association of Urology (EAU) Guidelines on Urological Infections pp. 247-269. ISBN 978-90-79754-91-5. https://www.uroweb.org/guidelines

Bouckaert J, Berglund J, Schembri M, De Genst E, Cools L, Wuhrer M, Hung CS, Pinkner J, Slattegard R, Zavialov A, Choudhury D, Langermann S, Hultgren SJ, Wyns L, Klemm P, Oscarson S, Knight SD, De Greve H (2005) Receptor binding studies disclose a novel class of high-affinity inhibitors of the Escherichia coli FimH adhesin. Mol Microbiol 55: 441-455. https://doi.org/10.1111/j.13652958.2004.04415.x

Brumbaugh AR, Mobley HL (2012) Preventing urinary tract infection: progress toward an effective Escherichia coli vaccine. Expert Rev Vaccines 11: 663-676. https://doi.org/10.1586/erv.12.36

Brumbaugh AR, Smith SN, Mobley HL (2013) Immunization with the yersiniabactin receptor, FyuA, protects against pyelonephritis in a murine model of urinary tract infection. Infect Immun 81: 3309-3316. https://doi.org/10.1128/IAI.00470-13

Cassini A, Plachouras D, Eckmanns T, Abu Sin M, Blank HP (2016) Burden of six healthcare-associated infections on European population health: estimating incidence-based disability-adjusted life years through a population prevalence-based modeling study. PLOS Med 13: e1002150. https://doi.org/10.1371/journal.pmed.1002150

Cecioni S, Imberty A, Vidal S (2015) Glycomimetics versus multivalent glycoconjugates for the design of high affinity lectin ligands. Chem Rev 115: 525-561. https://doi.org/10.1021/cr500303t

Cegelski L, Pinkner JS, Hammer ND, Cusumano CK, Hung CS, Chorell E, Aberg V, Walker JN, Seed PC, Almqvist F, Chapman MR, Hultgren SJ (2009) Small-molecule inhibitors target Escherichia coli amyloid biogenesis and biofilm formation. Nat Chem Biol 5: 913919. https://doi.org/10.1038/nchembio.242

Chanishvili N (2012) Phage therapy - history from Twort and d'Herelle through Soviet experience to current approaches. Adv Virus Res 83: 3-40. https://doi.org/10.1016/B978-0-12-394438-2.00001-3

Chapman MR, Robinson LS, Pinkner JS, Roth R, Heuser J, Hammar M, Normark S, Hultgren SJ (2002) Role of Escherichia coli curli operons in directing amyloid fiber formation. Science 295: 851-855. https://doi.org/10.1126/science.1067484

Chorell E, Pinkner JS, Phan G, Edvinsson S, Buelens F, Remaut H, Waksman G, Hultgren SJ, Almqvist F (2010) Design and synthesis of C-2 substituted thiazolo and dihydrothiazolo ring-fused 2-pyridones: pilicides with increased antivirulence activity. J Med Chem 53: 5690-5695. https://doi.org/10.1021/jm100470t

Chorell E, Bengtsson C, Sainte-Luce Banchelin T, Das P, Uvell H, Sinha AK, Pinkner JS, Hultgren SJ, Almqvist F (2011) Synthesis and application of a bromomethyl substituted scaffold to be used for efficient optimization of anti-virulence activity. Eur J Med Chem 46: 1103-1116. https://doi.org/10.1016/j.ejmech.2011.01.025

Chromek M, Slamová Z, Bergman P, Kovács L, Podracká L, Ehrén I, Hökfelt T, Gudmundsson G.H, Gallo RL, Agerberth B, Brauner A (2006) The antimicrobial peptide cathelicidin protects the urinary tract against invasive bacterial infection. Nat Med 12: 636-641. https://doi.org/10.1038/nm1407

Collins R, MacMahon S (2001) Reliable assessment of the effects of treatment on mortality and major morbidity, I: clinical trials. Lancet 357: 373-380. https://doi.org/10.1016/S0140-6736(00)03651-5

Conover MS, Ruer S, Taganna J, Kalas V, De Greve H, Pinkner JS, Dodson KW, Remaut H, Hultgren SJ (2016) Inflammation-induced adhesin-receptor interaction provides a fitness advantage to uropathogenic E. coli during chronic infection. Cell Host Microbe 20: 482-492. https://doi.org/10.1016/j.chom.2016.08.013

Cusumano CK, Pinkner JS, Han Z, Greene SA, Ford BA, Crowley JR, Henderson JP, Janetka JW, Hultgren SJ (2011) Treatment and prevention of urinary tract infection with orally active FimH inhibitors. Sci Transl Med 3: 109-115. https://doi.org/10.1126/scitranslmed.3003021

Dang HT, Chorell E, Uvell H, Pinkner JS, Hultgren SJ, Almqvist F (2014) Syntheses and biological evaluation of 2-amino-3-acyl-tetrahydrobenzothiophene derivatives; antibacterial agents with antivirulence activity. Org Biomol Chem 12: 1942-1956. https://doi. org/10.1039/c3ob42478b

Danilova TM (1996) Phage therapy of the inflammatory urogenital infections in women. Proc Dermatol Venerol 5: 75

Das M, Hart-Van Tassell A, Urvil PT, Lea S, Pettigrew D, Anderson KL, Samet A, Kur J, Matthews S, Nowicki S, Popov V, Goluszko P, Nowicki BJ (2005) Hydrophilic domain II of Escherichia coli Dr fimbriae facilitates cell invasion. Infect Immun 73: 6119-6126. https://doi.org/10.1128/IAI.73.9.6119-6126.2005

Dhakal BK, Mulvey MA (2012) The UPEC pore-forming toxin $\alpha$-hemolysin triggers proteolysis of host proteins to disrupt cell ad- 
hesion, inflammatory, and survival pathways. Cell Host Microbe 11: 58-69. https://doi.org/10.1016/j.chom.2011.12.003

Dodson KW, Pinkner JS, Rose T, Magnusson G, Hultgren SJ, Waksman G (2001) Structural basis of the interaction of the pyelonephritic E. coli adhesin to its human kidney receptor. Cell 105: 733743

Dueholm MS, Nielsen SB, Hein KL, Nissen P, Chapman M, Christiansen G, Nielsen PH, Otzen DE (2011) Fibrillation of the major curli subunit CsgA under a wide range of conditions implies a robust design of aggregation. Biochem 50: 8281-8290. https://doi. org/10.1021/bi200967c

European Centre for Disease Prevention and Control, European Food Safety Authority and European Medicines Agency (2017) ECDC/ EFSA/EMA second joint report on the integrated analysis of the consumption of antimicrobial agents and occurrence of antimicrobial resistance in bacteria from humans and food-producing animals. EFS A J 15: 4872. https://doi.org/10.2903/j.efsa.2017.4872

Flores-Mireles AL, Walker JN, Caparon M, Hultgren SJ (2015) Urinary tract infections: epidemiology, mechanisms of infection and treatment options. Nat Rev Microbiol 13: 269-284. https://doi. org/10.1038/nrmicro3432

Foxman B (2002) Epidemiology of urinary tract infections: incidence, morbidity, and economic costs. Am J Med 113: 5S-13S. https://doi. org/ 10.1016/S0002-9343(02)01054-9

Foxman B (2010) The epidemiology of urinary tract infection. Nat Rev Urol 7: 653-660. https://doi.org/ 10.1038/nrurol.2010.190

Foxman B (2014) Urinary tract infection syndromes: occurrence, recurrence, bacteriology, risk factors, and disease burden. Infect Dis Clin North Am 28: 1-13. https://doi.org/10.1016/j.idc.2013.09.003

Franco AV (2005) Recurrent urinary tract infections. Best Pract Res Clin Obstet Gynaecol 19: 861-873. https://doi.org/10.1016/j.bpobgyn.2005.08.003

Fronzes R, Remaut H, Waksman G (2008) Architectures and biogenesis of non-flagellar protein appendages in Gram negative bacteria. EMBO J 27: 2271-2280 https://doi.org/ 10.1038/emboj.2008.155

Garcia EC, Brumbaugh AR, Mobley HL (2011) Redundancy and specificity of Escherichia coli iron acquisition systems during urinary tract infection. Infect Immun 79: 1225-1235. https://doi.org/10.1128/ IAI.01222-10

Giancola SE, Mahoney MV, Hogan MD, Raux BR, McCoy C, Hirsch EB (2017) Assessment of fosfomycin for complicated or multidrug-resistant urinary tract infections: patient characteristics and outcomes. Chemotherapy 62: 100-104. https://doi. org/10.1159/000449422

Gordon N (2000) Carbohydrate-deficient glycoprotein syndromes. Postgrad Med J 76: 145-149. https://doi.org/10.1136/pmj.76.893.145

Goyal P, Krasteva PV, Van Gerven N, Gubellini F, Van den Broeck I, Troupiotis-Tsailaki A, Jonckheere W, Péhau-Arnaudet G, Pinkner JS, Chapman MR, Hultgren SJ, Howorka S, Fronzes R, Remaut $H$ (2014) Structural and mechanistic insights into the bacterial amyloid secretion channel CsgG. Nature 516: 250-253. https://doi. org/10.1038/nature13768

Goluszko P, Goluszko E, Nowicki B, Nowicki S, Popo V, Wang HQ (2005) Vaccination with purified Dr fimbraie reduces mortality associated with chronic urinary tract infection due to Escherichia coli bearing Dr adhesin. Infect Immun 73: 627-631. https://doi.org/10.1128/ IAI.73.1.627-631.2005

Goluszko P, Moseley SL, Truong LD, Kaul A, Williford JR, Selvarangan R, Nowicki S, Nowicki B (1997) Development of experimental model of chronic pyelonephritis with Escherichia coli O75:K5:H-bearing Dr fimbriae. J Clin Investig 99: 1662-1672. https://doi.org/ 10.1172/JCI119329

Goluszko P, Niesel D, Nowicki B, Selvarangan R, Nowicki S, Hart A, Pawelczyk E, Das M, Urvil P, Hasan R (2001) Dr operon-associated invasiveness of Escherichia coli from pregnant patients with pyelonephritis. Infect Immun 69: 4678-4680. https://doi.org/ 10.1128/ IAI.69.7.4678-4680

Gorski A, Dabrowska K, Switala-Jeleń K, Nowaczyk M, Weber-Dabrowska B, Boratynski J, Wietrzyk J, Opolski A (2003a) New insights into the possible role of bacteriophages in host defense and disease. Med Immunol 2: 2. https://doi.org/10.1186/1476-9433-2-2

Gorski A, Nowaczyk M, Weber-Dabrowska B, Kniotek M, Boratynski J, Ahmed A, Dabrowska K, Wierzbicki P, Switala-Jelen K, Opolski A (2003b) New insights into the possible role of bacteriophages in transplantation. Transplant Proc 35: 2372-2373. https://doi. org/10.1016/S0041-1345(03)00811-X

Greene SE, Pinkner JS, Chorell E, Dodson KW, Shaffer CL, Conover MS, Livny J, Hadjifrangiskou M, Almqvist F, Hultgren SJ (2014) Pilicide ec240 disrupts virulence circuits in uropathogenic Escherichia coli. mBio 5: e02038. https://doi.org/10.1128/mBio.02038-14

Guglietta A (2017) Recurrent urinary tract infections in women: risk factors, etiology, pathogenesis and prophylaxis. Future Microbiol 12: 239-246. https://doi.org/10.2217/fmb-2016-0145

Guiton PS, Cusumano, CK, Kline KA, Dodson KW, Han Z, Janetka JW, Henderson JP, Caparon MG, Hultgren SJ (2012) Combinatorial small-molecule therapy prevents uropathogenic Escherichia coli catheter-associated urinary tract infections in mice. Antimicrob Agents Chemother 56: 4738-4745. https://doi.org/10.1128/AAC.00447-12

Habibi A, Khameneie MK (2016) Antibiotic resistance properties of uropathogenic Escherichia coli isolated from pregnant women with history of recurrent urinary tract infections. Trop J Pharm Res 15: 1745-1750. https://dx.doi.org/10.4314/tjpr.v15i8.21

Hammar M, Bian Z, Normark S (1996) Nucleator-dependent intercellular assembly of adhesive curli organelles in Escherichia coli. Proc Natl Acad Sci USA 93: 6562-6566

Han Z, Pinkner JS, Ford B, Chorell E, Crowley JM, Cusumano CK, Campbell S, Henderson JP, Hultgren SJ, Janetka JW (2012) Lead optimization studies on FimH antagonists: discovery of potent and orally bioavailable ortho-substituted biphenyl mannosides. J Med Chem 55: 3945-3959. https://doi.org/10.1021/jm300165m

Han Z, Pinkner JS, Ford B, Obermann R, Nolan W, Wildman SA, Hobbs D, Ellenberger T, Cusumano CK, Hultgren SJ, Janetka JW (2010) Structure-based drug design and optimization of mannoside bacterial FimH antagonists. J Med Chem 53: 4779-4792. https://doi. org/10.1021/jm100438s

Hooton TM, Bradley SF, Cardenas DD, Colgan R, Geerlings SE, Rice JC, Saint S, Schaeffer AJ, Tambayh PA, Tenke P, Nicolle LE (2010) Diagnosis, prevention, and treatment of catheter-associated urinary tract infection in adults: 2009 international clinical practice guidelines from the Infectious Diseases Society of America. Clin Infect Dis 50: 625-663

Hu X, Shi Y, Zhang P, Miao M, Zhang T, Jiang B (2016) D-mannose: properties, production, and applications: an overview. Rev Food Sci Food Saf 15: 773-785. https://doi.org/10.1111/1541-4337.12211

Hung DL, Knight SD, Woods RM, Pinkner JS, Hultgren SJ (1996) Molecular basis of two subfamilies of immunoglobulin-like chaperones. EMBO J 15: 3792-3805. https://doi.org/10.1002/j.1460-2075.1996. tb00753.x

Kleeb S, Pang, L, Mayer K, Eris D, Sigl A, Preston RC, Zihlmann P, Sharpe T, Jakob RP, Abgottspon D, Hutter AS, Scharenberg M, Jiang X, Navarra G, Rabbani S, Smiesko M, Lüdin N, Bezençon J, Schwardt O, Maier T, Ernst B (2015) FimH antagonists: bioisosteres to improve the in vitro and in vivo $\mathrm{PK} / \mathrm{PD}$ profile. $J$ Med Chem 58: 2221-2239. https://doi.org/10.1021/jm501524q

Klein T, Abgottspon D, Wittwer M, Rabbani S, Herold J, Jiang X, Kleeb S, Luthi C, Scharenberg M, Bezenuon J, Gubler E, Pang L, Smiesko M, Cutting B, Schwardt O, Ernst B. (2010) FimH antagonists for the oral treatment of urinary tract infections: From design and synthesis to in vitro and in vivo evaluation. J Med Chem 53: 8627-8641. https://doi.org/10.1021/jm101011y

Klemm P, Schembri MA (2000) Fimbriae-assisted bacterial surface display of heterologous peptides. Int J Med Microbiol 290: 215-221. https://doi.org/10.1099/00221287-146-12-3025

Kline KA, Dodson KW, Caparon MG, Hultgren SJ (2010) A tale of two pili: assembly and function of pili in bacteria. Trends Microbiol 18: 224-232. https://doi.org/10.1016/j.tim.2010.03.002.

Kochiashvili D, Khuskivadze A, Kochiashvili G, Koberidze G, Kvakhajelidze V (2014) Role of the bacterial vaccine Solco-Urovac ${ }^{\circledR}$ in treatment and prevention of recurrent urinary tract infections of bacterial origin. Georgian Med News 231: 11-16

Kostakioti M, Hultgren SJ, Hadjifrangiskou M (2012) Molecular blueprint of uropathogenic Escherichia coli virulence provides clues toward the development of anti-virulence therapeutics. Virulence 3: 592-594. https://doi.org/10.4161/viru.22364

Langermann S, Möllby R, Burlein JE, Palaszynski SR, Auguste CG, DeFusco A, Strouse R, Schenerman MA, Hultgren SJ, Pinkner SJ, Winberg J, Guldevall L, Söderhäll M, Ishikawa K, Normark S, Koenig $\mathrm{S}(2000)$ Vaccination with FimH adhesin protects cynomolgus monkeys from colonization and infection by uropathogenic Escherichia coli. J Infect Dis 181: 774-778. https://doi.org/10.1086/315258

Langermann S, Palaszynski S, Barnhart M, Auguste G, Pinkner JS, Burlein J, Barren P, Koenig S, Leath S, Jones CH, Hultgren SJ (1997) Prevention of mucosal Escherichia coli infection by FimH-adhesin-based systemic vaccination. Science 276: 607-611. https://doi. org/10.1126/science.276.5312.607

Leffler H, Svanborg-Edén C (1981) Glycolipid receptors for uropathogenic Escherichia coli on human erythrocytes and uroepithelial cells. Infect Immun 34: 920-929

Leitner L, Sybesma W, Chanishvili N, Goderdzishvili M., Chkhotua, A.,Ujmajuridze, A., Schneider MP, Sartori A, Mehnert U, Bachmann LM, Kessler TM (2017). Bacteriophages for treating urinary tract infections in patients undergoing transurethral resection of the prostate: a randomized, placebo-controlled, double-blind clinical trial. BMC Urol 17: 90. https://doi.org/10.1186/s12894-017-0283-6

Letkiewicz S, Miedzybrodzki R, Klak M, Jonczyk E, Weber-Dabrowska B, Gorski A (2010) The perspectives of the application of phage therapy in chronic bacterial prostatitis. FEMS Immunol Med Microbiol 60: 99-112. https://doi.org/10.1111/j.1574-695X.2010.00723.x

Lindhorst TK, Bruegge K, Fuchs A, Sperling O (2010) A bivalent glycopeptide to target two putative carbohydrate binding sites on FimH. Beilstein J Org Chem 6: 801-809. https://doi.org/10.3762/ bjoc. 6.90 
Loferer H, Hammar M, Normark S (1997) Availability of the fibre subunit CsgA and the nucleator protein $\mathrm{CsgB}$ during assembly of fibronectin-binding curli is limited by the intracellular concentration of the novel lipoprotein CsgG. Mol Microbiol 26: 11-23

MacMahon S, Collins R (2001) Reliable assessment of the effects of treatment on mortality and major morbidity, II: observational studies. Lancet 357: 455-62. https://doi.org/10.1016/S01406736(00)04017-4

Maddirala A, Klein RD, Pinkner J, Kalas V, Hultgren SJ, Janetka JW (2018) Biphenyl Gal and GalNAc FmlH Lectin Antagonists of Uropathogenic E. coli (UPEC): Optimization through iterative rational drug design. I Med Chem 62: 467-479. https://doi. org/10.1021/acs.jmedchem.8b01561

Mike LA, Smith SN, Sumner CA, Eaton KA, Mobley HL (2016) Siderophore vaccine conjugates protect against uropathogenic Escherichia coli urinary tract infection. Proc Natl Acad Sci U S A 113: 13468 13473. https://doi.org/10.1073/pnas.1606324113

Mousavifar L, Touaibia M, Roy R (2018) Development of mannopyranoside therapeutics against adherent-invasive Escherichia coli infections. Acc Chem Res 51: 2937-2948. https://doi.org/10.1021/acs. accounts.8b00397

Naber KG, Cho YH, Matsumoto T, Schaeffer AJ (2009) Immunoactive prophylaxis of recurrent urinary tract infections: a meta-analysis. Int J Antimicrob Agents 33: 111-119. https://doi.org/10.1016/j.ijantimicag.2008.08.011

Nenninger AA, Robinson LS, Hultgren SJ (2009) Localized and efficient curli nucleation requires the chaperone-like amyloid assembly protein CsgF. Proc Natl Acad Sci USA 106: 900-905. https://doi. org/10.1073/pnas.0812143106

Neto TKA, Nogueira CL, Reis LO (2016) Oral vaccine (OM-89) in the recurrent urinary tract infection prophylaxis: a realistic systematic review with meta-analysis. Actas Urol Esp 40: 203-208. https://doi. org/10.1016/j.acuro.2015.04.008

Nicolle LE, Bradley S, Colgan R, Rice JC, Schaeffer A, Hooton TM (2005) Infectious diseases society of America guidelines for the diagnosis and treatment of asymptomatic bacteriuria in adults. Clin Infect Dis 40: 643-654. https://doi.org/10.1086/427507

Nielsen KL, Dynesen P, Larsen P, Jakobsen L, Andersen PS, Frimodt-Møller N (2014) Role of urinary cathelicidin LL-37 and human $\beta$-defensin 1 in uncomplicated Escherichia coli urinary tract infections. Infect Immun 82: 1572-1578. https://doi.org/10.1128/ IAI.01393-13

Nowicki B, Martens M, Hart A, Nowicki S (1994) Gestational age-dependent distribution of Escherichia coli fimbriae in pregnant patients with pyelonephritis. Ann N Y Acad Sci 730: 290-291. https://doi. org/10.1111/j.1749-6632.1994.tb44268.x

Nowicki B, Rhen M, Väisänen-Rhen V, Pere A, Korhonen TK (1984) Immunofluorescence study of fimbrial phase variation in Escherichia coli KS71. I Bacteriol 160: 691-695. https://doi.org/00219193/84/110691-05\$02.00/0

O'Brien VP, Dorsey DA, Hannan TJ, Hultgren SJ (2018) Host restriction of Escherichia coli recurrent urinary tract infection occurs in a bacterial strain-specific manner. PLoS Pathog 14: e1007457. https:// doi.org/10.1371/journal.ppat.1007457

O’Hanley P, Lalonde G, Ji G (1991) Alpha-hemolysin contributes to the pathogenicity of piliated digalactoside-binding Escherichia coli in the kidney: efficacy of an alpha-hemolysin vaccine in preventing renal injury in the BALB/c mouse model of pyelonephritis. Infect Immun 59: 1153-1161

Perepanova TS, Darbeeva OS, Kotliarova GA, Kondrat'eva EM, Măskaia LM, Malysheva VF, Băguzina FA, Grishkova N (1995) The efficacy of bacteriophages preparations in treatment of inflammatory urogenital diseases. Urol Nephrol 5: 14-17

Piątek R, Zalewska-Piątek B, Dzierzbicka K, Makowiec S, Pilipczuk J, Szemiako K, Cyranka-Czaja A, Wojciechowski M (2013) Pilicides inhibit the FGL chaperone/usher assisted biogenesis of the fimbrial polyadhesin from uropathogenic Escherichia coli. BMC Microbiol 13: 131. https://doi.org/10.1186/1471-2180-13-131

Pinkner JS, Remaut H, Buelens F, Miller E, Aberg V, Pemberton N, Hedenström M, Larsson A, Seed P, Waksman G, Hultgren SJ, Almqvist F (2006) Rationally designed small compounds inhibit pilus biogenesis in uropathogenic bacteria. Proc Natl Acad Sci USA 103: 17897-17902. https://doi.org/10.1073/pnas.0606795103

Pirnay JP, Blasdel BG, Bretaudeau L, Buckling A, Chanishvili N, Clark JR, Corte-Real S, Debarbieux L, Dublanchet A, De Vos D, Gabard J, Garcia M, Goderdzishvili M, Górski A, Hardcastle J, Huys I, Kutter E, Lavigne R, Merabishvili M, Olchawa E, Parikka KJ Patey O, Pouilot F, Resch G, Rohde C, Scheres J, Skurnik M, Vaneechoutte M, Van Parys L, Verbeken G, Zizi M, Van den Eede G (2015) Quality and safety requirements for sustainable phage therapy products. PharmRes 32: 2173-2179. https://doi.org/10.1007/ apy products. Pharm

Pirnay JP, De Vos D, Verbeken G, Merabishvili M, Chanishvili N, Vaneechoutte M, Zizi M, Laire G, Lavigne R, Huys I, Van den Mooter G, Buckling A, Debarbieux L, Pouillot F, Azeredo J, Kutter E, Dublanchet A, Górski A, Adamia R (2011) The phage therapy para- digm: pret-a- porter or sur-mesure? PharmRes 28: 934-937. https:// doi.org/10.1007/s11095-010-0313-5

Remaut H, Rose RJ, Hannan TJ, Hultgren SJ, Radford SE, Ashcroft AE, Waksman G (2006) Donor-strand exchange in chaperoneassisted pilus assembly proceeds through a concerted beta strand displacement mechanism. Mol Cell 22: 831-842. https://doi. org/10.1016/j.molcel.2006.05.033

Remaut H, Tang C, Henderson N, Pinkner J,Wang T, Hultgren S, Thanassi D,Waksman G, Li H (2008) Fiber formation across the bacterial outer membrane by the chaperone/usher pathway. Cell 133: 640-652. https://doi.org/10.1016/i.cell.2008.03.033

Roberts JA, Hardaway K, Kaack B, Fussell EN, Baskin G (1984) Prevention of pyelonephritis by immunization with P-fimbriae. J Urol 131: 602-607. https://doi.org/10.1016/S0022-5347(17)50513-3

Roberts JA, Kaack MB, Baskin G, Chapman MR, Hunstad DA, Pinkner JS, Hultgren SJ (2004) Antibody responses and protection from pyelonephritis following vaccination with purified Escherichia coli PapDG protein. I Urol 171: 1682-1685. https://doi. org/10.1097/01.ju.0000116123.05160.43

Roberts JA, Marklund BI, Ilver D, Haslam D, Kaack MB, Baskin G, Louis M, Möllby R, Winberg J, Normark S (1994) The Gal(alpha 1-4)Gal-specific tip adhesin of Escherichia coli P-fimbriae is needed for pyelonephritis to occur in the normal urinary tract. Proc Natl Acad Sci USA 91: 11889-11893. https://doi.org/10.1073/ pnas.91.25.11889

Robinson LS, Ashman EM, Hultgren SJ, Chapman MR (2006) Secretion of curli fibre subunits is mediated by the outer membranelocalized CsgG protein. Mol Microbiol 59: 870-881. https://doi. org/10.1111/j.1365-2958.2005.04997.x

Russo TA, McFadden CD, Carlino-MacDonald UB, Beanan JM, Olson $\mathrm{R}$, Wilding GE (2003) The Siderophore receptor IroN of extraintestinal pathogenic Escherichia coli is a potential vaccine candidate. In fect Immun 71: 7164-7169. https://doi.org/10.1128/IAI.71.12.71647169.2003

Sauer MM, Jakob RP, Eras J, Baday S, Eriş D, Navarra G, Bernèche S, Ernst B, Maier T, Glockshuber R (2016) Catch-bond mechanism of the bacterial adhesin FimH. Nat Commun 7: 10738. https://doi. org/10.1038/ncomms10738

Savar NS, Jahanian-Najafabadi A, Mahdavi M, Shokrgozar MA, Jafari A, Bouzari S (2014) In silico and in vivo studies of truncated forms of flagellin (FliC) of enteroaggregative Escherichia coli fused to FimH from uropathogenic Escherichia coli as a vaccine candidate against urinary tract infections. J Biotechnol 175: 31-37. https://doi. org/10.1016/j.jbiotec.2014.01.037

Sivick KE, Mobley HL (2010) Waging war against uropathogenic Escherichia coli: winning back the urinary tract. Infect Immun 78: 568-585. https://doi.org/10.1128/IAI.01000-09

Sokurenko EV, Chesnokova V, Doyle RJ, Hasty DL (1997) Diversity of the Escherichia coli type 1 fimbrial lectin. Differential binding to mannosides and uroepithelial cells. I Biol Chem 272: 17880-17886

Soto GE, Hultgren SJ (1999) Bacterial adhesins: common themes and variations in architecture and assembly. I Bacteriol 181: 1059-1071. https://doi.org/10.1111/j.1574-6976.2007.00075.x

Spaulding CN, Hultgren SJ (2016) Adhesive pili in UTI pathogenesis and drug development Pathogen 5: E30. https://doi.org/10.3390/ pathogens 5010030

Spaulding CN, Schreiber HL 4th, Zheng W, Dodson KW, Hazen JE, Conover MS, Wang F, Svenmarker P, Luna-Rico A, Francetic O, Andersson M, Hultgren S, Egelman EH (2018) Functional role of the type 1 pilus rod structure in mediating host-pathogen interactions. eLife 7 pii: e31662. https://doi.org/10.7554/eLife.31662

Stamm WE, Norrby SR (2001) Urinary tract infections: disease panorama and challenges. I Infect Dis 183: S1-S4. https://doi. org/10.1086/318850

Stork C, Kovács B, Rózsai B, Putze J, Kiel M, Dorn Á, Kovács J, Melegh S, Leimbach A, Kovács T, Schneider G, Kerényi M, Emödy L, Dobrindt U (2018) Characterization of asymptomatic bacteriuria Escherichia coli isolates in search of alternative strains for efficient bacterial interference against uropathogens. Front Microbiol 9: 214. https://doi.org/10.3389/fmicb.2018.00214

Svennson A, Larsson A, Erntenäs H, Hedenström M, Fex T, Hulgren S, Pinker J, Almqvist F, Kihlberg J (2001) Design and evaluation of pilicides: potential novel antibacterial agents directed against uropathogenic Escherichia coli. Chembiochem 2: 915-918

Sybesma W, Zbinden R, Chanishvili N, Kutateladze M, Chkhotua A, Ujmajuridze A, Mehnert U, Kessler TM (2016) Bacteriophages as potential treatment for urinary tract infections. Front Microbiol 7: 465. https://doi.org/10.3389/fmicb.2016.00465

Terlizzi ME, Gribaudo G, Maffei ME (2017) UroPathogenic Escherichia coli (UPEC) Infections: virulence factors, bladder responses, antibiotic, and non-antibiotic antimicrobial strategies. Front Microbiol 8: 1566. https://doi.org/10.3389/fmicb.2017.01566

Thanassi DG, Saulino ET, Hultgren SJ (1998) The chaperone/usher pathway: a major terminal branch of the general secretory pathway. Curr Opin Microbiol 1: 223-231. https://doi.org/10.1016/S13695274(98)80015-5 
Tomašić T, Rabbani S, Gobec M, Raščan IM, Podlipnik Č, Ernst B, Anderluh M (2014) Branched $\alpha$-D-mannopyranosides: a new class of potent FimH antagonists. Med Chem Commun 5: 1247-1253. https://doi.org/10.1039/C4MD00165F

Totsika M, Kostakioti M, Hannan TJ, Upton M, Beatson SA, Janetka JW, Hultgren SJ, Schembri MA (2013) A FimH inhibitor prevents acute bladder infection and treats chronic cystitis caused by multidrug-resistant uropathogenic Escherichia coli ST131. I Infect Dis 208: 921-928. https://doi.org/10.1093/infdis/jit245

Touaibia M, Roy R (2007) Glycodendrimers as anti-adhesion drugs against type 1 fimbriated E. coli uropathogenic infections. Mini-Rev Med Chem 7: 1270-1283

Ujmajuridze A, Chanishvili N, Goderdzishvili M, Leitner L, Mehnert U, Chkhotua A, Kessler TM, Sybesma W (2018) Adapted bacteriophages for treating urinary tract infections. Front Microbiol 9: 1832. https://doi.org/10.3389/fmicb.2018.01832

Valore EV, Park CH, Quayle AJ, Wiles KR, McCray PB Jr, Ganz T (1998) Human beta-defensin-1: an antimicrobial peptide of urogenital tissues. J Clin Invest 101: 1633-1642. https://doi.org/10.1172/ JCI1861

Vandenbroucke JP (2004) When are observational studies as credible as randomised trials? Lancet 363: 1728-1731. https://doi.org/10.1016/ S0140-6736(04)16261-2

Waksman G, Hultgren SJ (2009) Structural biology of the chaperone-usher pathway of pilus biogenesis. Nat Rev Microbiol 7: 765-774. https://doi.org/10.1038/nrmicro2220

Wang X, Smith DR, Jones JW, Chapman MR (2007) In vitro polymerization of a functional Escherichia coli amyloid protein. J Biol Chem 282: 3713-3719. https://doi.org/10.1074/jbc.M609228200

Weber-Dabrowska B, Dabrowski M, Slopek S (1987) Studies on bacteriophage penetration in patients subjected to phage therapy. Arch Immunol Ther Exp (Warsz) 35: 563-568
Weber-Dabrowska B, Mulczyk M, Górski A (2003) Bacteriophages as an efficient therapy for antibiotic-resistant septicemia in man. Transplant Proc 35: 1385-1386

Werneburg GT, Thanassi DG (2018) Pili assembled by the chaperone/ usher pathway in Escherichia coli and Salmonella. EcoSal Plus 8: 1-37. https://doi.org/10.1128/ecosalplus

Wolski Z (2017) The application of Uro-Vaxom in the prevention and treatment of urinary tract infections caused by bacteria other than colon Escherichia coli. Przegl Urol 3: 1-26 (in Polish)

Wurpel DJ, Beatson SA, Totsika M, Petty NK, Schembri MA (2013) Chaperone-usher fimbriae of Escherichia coli. PLoS One 8: e52835. https://doi.org/10.1371/journal.pone.0052835

Zalewska B, Piatek R, Konopa G, Nowicki B, Nowicki S, Kur J (2003) Chimeric Dr fimbriae with a herpes simplex virus type 1 epitope as a model for a recombinant vaccine. Infect Immun 71: 5505-5513. https://doi.org/10.1128/IAI.71.10.5505-5513.2003

Zalewska B, Stangret J, Bury K, Wojciechowski M, Kur J, Piatek R (2007) DAF- and collagen-binding properties of chimeric Dr fimbriae. Microbiol 153: 2733-2742. https://doi.org/10.1099/ mic.0.2006/003525-0

Zavialov A, Zav'yalova G, Korpela T, Zav'yalov V (2007) FGL chaperone-assembled fimbrial polyadhesins: anti-immune armament of Gram-negative bacterial pathogens. FEMS Microbiol. Rev 31: 478514. https://doi.org/10.1111/j.1574-6976.2007.00075.x

Zav'yalov V, Zavialov A, Zav'valova G, Korpela T (2010) Adhesive organelles of Gram-negative pathogens assembled with the classical chaperone/usher machinery: structure and function from a clinical standpoint. FEMS Microbiol Rev 34: 317-378. https://doi. org/10.1111/j.1574-6976

Zowawi HM, Harris PN, Roberts MJ, Tambyah PA, Schembri MA, Pezzani MD, Williamson DA, Paterson DL (2015) The emerging threat of multidrug-resistant Gram-negative bacteria in urology. Nat Rev Urol 12: 570-584. https://doi.org/10.1038/nrurol.2015.199 